\title{
Coinfection of hepatitis $B$ and hepatitis $C$ virus among chronic liver disease patients in a tertiary care centre
}

\author{
Vilas BN. ${ }^{1}$, Lyra PR. $^{2}$, Venkatesha $D .^{3}$ \\ ${ }^{1}$ Dr. Vilas B N., Assistant Surgeon, Sanjay Gandhi Institute of trauma and Orthopedics, Bangalore, Karnataka, ${ }^{2}$ Dr. Lyra \\ P.R., Assistant Professor, Department of Microbiology, East Point College Of Medical Sciences \& Research Centre, \\ Bangalore, Karnataka, ${ }^{3}$ Dr. Venkatesha D., Professor \& HOD, Department Of Microbiology, Adichunchanagiri Institute \\ of Medical Sciences, Bellur, Karnataka, India.
}

Corresponding Author: Dr. Lyra P R, Assistant Professor of Microbiology, East Point College Of Medical Sciences \& Research Centre, Bangalore, Karnataka, India. Email: drlyrapr@gmail.com

\begin{abstract}
Background: Hepatitis B virus (HBV) and hepatitis C virus (HCV) are the most common cause of chronic liver disease (CLD) worldwide. Coinfection with both HBV and HCV can occur because of shared routes of infection. Therefore, this study was performed to investigate the seroprevalence of $\mathrm{HBV}$ and $\mathrm{HCV}$ dual infection among patients attending $\mathrm{K} \mathrm{R}$ hospital, Mysore with underlying CLD manifestations. Materials \& Methods: Serum samples from 80 clinically diagnosed chronic liver disease patients attending K R hospital, Mysorewas screened for the presence of hepatitis B surface antigen, Anti-HBc IgM, Anti-HBc Ig Gand anti-hepatitis C virus antibodies by ELISA. Serum samples from 15 healthy individuals were also screened. Results: Among 80 chronic liver disease patients, 67 (83.75\%) were males and $13(16.25 \%)$ were females. The maximum number of CLD patients was in the age group of $41-50$ years $(41.30 \%)$. Alcoholism (72.5\%) was the most common risk factor \& cirrhosis of liver was the most common clinical presentation (81.25\%). 38 (47.5\%) cases were HBV positive (positive for any one marker for HBV). HBs Ag was positive in 22 cases, anti-HBc Ig Min 7 cases, anti-HBc Ig Gin 29 cases. 4 (5\%) cases were positive for anti HCV. Three (3.75\%) cases showed coinfection of HBV \& HCV.Conclusion: To prevent the spread of HBV and HCV, people must be educated about these infections and their mode of transmission. All CLD patients should be tested for HBV and HCV to prevent the mortality and morbidity. HBV \& HCV coinfection should not be excluded by negative HBsAg status alone.
\end{abstract}

Key words: Chronic liver disease, HBV, HCV, Dual infection, ELISA

\section{Introduction}

Hepatitis B virus (HBV) and hepatitis C virus (HCV) are the most common causes of chronic liver disease (CLD) world wide [1]. Coinfection with both HBV and $\mathrm{HCV}$ can occur because of shared routes of infection [24]. Approximately 400 million people are reported to be infected with HBV worldwide [5] and the Center for Disease Control and Prevention estimates that approximately 170 million people are infected with HCV [6]. The exact number of patients infected with both HCV and HBV worldwide is unknown [7].

Majority of those withchronic HBV and/or HCV infection will develop complications i.e. $15 \%-40 \%$ may develop cirrhosis, liverfailure and or hepatocellular carcinoma (HCC) [8]. Coinfection of HBs Ag negative

Manuscript received: $20^{\text {th }}$ March 2018

Reviewed: $30^{\text {th }}$ March 2018

Author Corrected: $6^{\text {th }}$ April 2018

Accepted for Publication: $11^{\text {th }}$ April 2018
HBV (silent HBV) \& HCV in CLD cases has also been reported [9]. Over the next 20 years, there will be an increase in the proportion of $\mathrm{HBV} / \mathrm{HCV}$ infected patients with cirrhosis from $16 \%$ to $32 \%$, HCCby $81 \%$ and liver related deathsby $180 \%$ [10].

The clinical presentations and disease outcomes are usuallymore severe in patients with coinfection than in patients with single hepato tropic virus infection $[11,12,13,14]$. Hence identification of such patients and selection of the optimal antiviral therapy is a challenge for clinicians [15]. The prevalence of $\mathrm{HBV}$ and $\mathrm{HCV}$ co-infection in India has been reported to range from $3 \%$ to $56 \%[16,17,18]$.

The difference in the magnitude of co-infectioncould be due to difference inthe study population, geographical variation, and difference in methodology [19]. 
Therefore, this study was performed to estimatethe seroprevalence of $\mathrm{HBV}$ and $\mathrm{HCV}$ dual infection amongpatients attending $\mathrm{K} \mathrm{R}$ hospital, Mysorewith underlying CLD manifestations.

\section{Materials \& Methods}

Study type \& place: The prospective study was carried out in the Department Of Microbiology, Mysore Medical College and Research Institute, Mysore. Eighty patients with clinically suspected chronicliver disease, attending the outpatient department (OPD) oradmitted in the wards of $\mathrm{K} R$ hospital attached to Mysore Medical College \& Research institute, Mysore during the year January 2012 to December 2012 were included in the study. 15 asymptomatic healthy individuals constituted the control group. Informed consent was obtained and caseswere interviewed to collect data on sociodemographic and risk factors using predesigned questionnaire.

\section{Inclusion criteria}

1. Alcoholic liver diseases.

2. All cases of chronic liver disease with raised AST and ALT levels.

3. History of exposure: heterosexual and homosexual.

4. History of blood transfusion and blood products.

5. History of intravenous drug abuse.

\section{Exclusion criteria}

\section{Original Research Article}

1. All cases of acute hepatitis.

2. Patients other than Chronic Liver Disease

Sample Collection: Under aseptic precautions five millilitre of blood sample was collected, serum separated, aliquoted and stored at $-20^{\circ} \mathrm{C}$ until testing done. HBs Ag (Erba Lisa Hepatitis B - ELISA) AntiHBcIgM, (DRG® Anti-Hepatitis B Core Antigen IgM ELISA), Anti-HBc IgG (DRG® Anti-Hepatitis B Core Antigen IgG ELISA (EIA-3894) \& Anti -HCV (Erba Lisa Hepatitis C - third generation ELISA) were detected by using commercially available kits.

Serum samples from 15 healthy individuals were also screened for the HBs Ag, anti HBcIg M, anti-HBc IgG and anti-HCV as per the methodology. Serum samples positive for any one marker (HBsAg, anti $\mathrm{HBcIg} \mathrm{M}$, anti-HBc $\mathrm{IgG}$ ) was considered as $\mathrm{HBV}$ positive andpositive for anti $\mathrm{HCV}$ was considered as $\mathrm{HCV}$ positive [18].

Statistical analysis: All the statistical methods were carried out through the SPSS for Windows (version 16.0) and Minitab for windows (version 11.0). Pearson's Chi square test and student's t test was used to find significance of the results. The $\mathrm{p}$ value $<0.05$ is considered statistically significant.

\section{Results}

Table-1: Age and sex distribution of chronic liver disease cases screened.

\begin{tabular}{|c|c|c|c|}
\hline \multirow{2}{*}{$\begin{array}{l}\text { Age group } \\
\text { (years) }\end{array}$} & \multirow{2}{*}{$\begin{array}{c}\text { Number of patients } \\
(\%)\end{array}$} & Male & Female \\
\hline & & $\begin{array}{c}\text { Number of patients } \\
(\%)\end{array}$ & $\begin{array}{c}\text { Number of patients } \\
(\%)\end{array}$ \\
\hline $21-30$ & $\begin{array}{c}8 \\
(10.00 \%) \\
\end{array}$ & $\begin{array}{c}8 \\
(10 \%)\end{array}$ & $\begin{array}{c}0 \\
(0 \%)\end{array}$ \\
\hline $31-40$ & $\begin{array}{c}19 \\
(23.80 \%)\end{array}$ & $\begin{array}{c}16 \\
(20 \%)\end{array}$ & $\begin{array}{c}3 \\
(3.75 \%)\end{array}$ \\
\hline $41-50$ & $\begin{array}{c}33 \\
(41.30 \%)\end{array}$ & $\begin{array}{c}25 \\
(31.25 \%)\end{array}$ & $\begin{array}{c}8 \\
(10 \%)\end{array}$ \\
\hline $51-60$ & $\begin{array}{c}14 \\
(17.50 \%)\end{array}$ & $\begin{array}{c}14 \\
(17.5 \%)\end{array}$ & $\begin{array}{c}0 \\
(0 \%)\end{array}$ \\
\hline 61 and more & $\begin{array}{c}6 \\
(7.50 \%)\end{array}$ & $\begin{array}{c}4 \\
(5 \%)\end{array}$ & $\begin{array}{c}2 \\
(2.5 \%)\end{array}$ \\
\hline Total & $\begin{array}{c}80 \\
(100 \%)\end{array}$ & $\begin{array}{c}67 \\
(83.75 \%)\end{array}$ & $\begin{array}{c}13 \\
(16.25 \%)\end{array}$ \\
\hline
\end{tabular}

P value $-\mathbf{0 . 3 1 0}$

Among 80 chronic liver disease patients, 67 (83.75\%) were males and 13 (16.25\%) were females. The maximum number of chronic liver disease patients were in the age group of $41-50$ years $(41.30 \%)$, followed by $31-40$ years $(23.80 \%), 51$ -60 years $(17.50 \%), 21-30$ years $(10 \%)$ and $>60$ years $(7.50 \%)$. 
Original Research Article

Table-2: Chronic liver disease according to risk factors.

\begin{tabular}{|c|c|c|c|c|}
\hline History & $\begin{array}{l}\text { Chronic } \\
\text { hepatitis }\end{array}$ & Cirrhosis of liver & $\begin{array}{c}\text { Hepatocellular } \\
\text { carcinoma }\end{array}$ & $\begin{array}{c}\text { Total number } \\
(\%)\end{array}$ \\
\hline Alcohol & 11 & 47 & Nil & $\begin{array}{c}58 \\
(72.5 \%)\end{array}$ \\
\hline Sexual exposure & Nil & 1 & Nil & $\begin{array}{c}1 \\
(1.25 \%)\end{array}$ \\
\hline $\begin{array}{c}\text { Alcohol with sexual } \\
\text { exposure }\end{array}$ & 1 & 6 & 1 & $\begin{array}{c}8 \\
(10 \%)\end{array}$ \\
\hline H/O Jaundice & Nil & 2 & Nil & $\begin{array}{c}2 \\
(2.5 \%)\end{array}$ \\
\hline Alcohol with $\mathbf{h} / \mathrm{o}$ jaundice & Nil & 5 & Nil & $\begin{array}{c}5 \\
(6.25 \%)\end{array}$ \\
\hline No risk factor & 2 & 4 & Nil & $\begin{array}{c}6 \\
(7.5 \%)\end{array}$ \\
\hline Total & 14 & 65 & 1 & $\begin{array}{c}80 \\
(100 \%)\end{array}$ \\
\hline
\end{tabular}

$P$ value- 0.041

Most common risk factor was alcoholism $(72.5 \%) \&$ cirrhosis of liver was the most common clinical presentation $(81.25 \%)$.

Table-3: Association of $\mathrm{HBV}$ and $\mathrm{HCV}$ in CLD cases.

\begin{tabular}{|c|c|c|c|}
\hline $\begin{array}{l}\text { Total number of } \\
\text { chronic liver disease } \\
\text { patients screened }\end{array}$ & $\begin{array}{l}\text { Number of HBV positive } \\
(\%) \text { (positive forany one } \\
\text { marker for } \mathrm{HBV})\end{array}$ & $\begin{array}{c}\text { Number of HCV positive } \\
(\%)(\text { positive for anti } \\
\text { HCV) }\end{array}$ & $\begin{array}{c}\text { Number of } \\
\text { HBV and HCV } \\
\text { positive }(\%)\end{array}$ \\
\hline 80 & $\begin{array}{c}38 \\
(47.5 \%)\end{array}$ & $\begin{array}{c}4 \\
(5 \%)\end{array}$ & $\begin{array}{c}3 \\
(3.75 \%)\end{array}$ \\
\hline
\end{tabular}

$P$ value-0 .258

Among the $38 \mathrm{HBV}$ positive cases 22 were $\mathrm{Hbs}$ Ag positive, 7 were anti Hbc IgM positive, 29 were anti $\mathrm{HbcIg}$ G positive.

Table-4: Clinical presentation of $\mathrm{HBV}$ and $\mathrm{HCV}$ co-infection cases

\begin{tabular}{|c|c|c|}
\hline Disease & Number screened & $\begin{array}{c}\text { Number positive } \\
(\%)\end{array}$ \\
\hline Chronic hepatitis & 14 & Nil \\
\hline Cirrhosis of liver & 65 & $(66.7 \%)$ \\
\hline Hepatocellular carcinoma & 1 & 1 \\
\hline Total & 80 & $33.3 \%)$ \\
\hline
\end{tabular}

Sexual exposure $(100 \%)$ was the predominant mode of transmission in co-infection cases.

The mean AST and ALT levels were elevated compared to normal reference values.

All the 15 healthy controls studied, were negative for HBV and HCV. 
Original Research Article

\section{Discussion}

$\mathrm{HBV}$ and $\mathrm{HCV}$ infections are among the most prevalent infectious diseases in humans worldwide. Both infections are associated with a broad range of clinical presentations ranging from acute or fulminant hepatitis to chronic infection that may be clinically asymptomatic or may progress to chronic hepatitis and liver cirrhosis. Co-infection with the two viruses is not uncommon, especially among people at high risk for parenteral infection and in areas with a high prevalence of HBV infection [20]. Coinfection with evidence of chronic $\mathrm{HBV}$ and $\mathrm{HCV}$ seems to result in more severe liver disease than either infection alone, with an increase risk of liver cancer [21] and probably an increasedrisk of fulminant hepatitis when superinfection with $\mathrm{HCV}$ on the background of chronic HBV. In our study the detection of co-infection with both $\mathrm{HBV}$ and $\mathrm{HCV}$ in CLD patients was based on the presence of combination of $\mathrm{HBs} \mathrm{Ag}$, anti Hbc IgM, anti Hbc IgG, and anti-HCV $\mathrm{Ab}$.

Age distribution of CLD patients in this study showed that $41.30 \%$ of CLD cases were in the age group of 41 50 yrs followed by $23.80 \%$ in the age group $31-40$ yrs. This is comparable with a study done by Kooffrehet al where it was found that most CLD patients were in the third and fourth decades of life [22].

Among 80 chronic liver disease patients, 67 (83.75\%) were males and $13(16.25 \%)$ were females. The increase in the cases among males could be due to certain life style habitslike alcohol consumption and smoking. This might also be due to fact that males make more common visits to barbers and they are more probable to get wounded and share equipments. Moreover, men are more likely to have many sex partners and follow unprotected sex.

In the present study the most common risk factor was alcoholism $(72.5 \%)$. A study conducted by Kooffreh et a showed that alcohol was the main etiologic agent in CLD cases and the risk of developing cirrhosis increaseswith the ingestion of $>60-80 \mathrm{~g} /$ day of alcohol for 10 years in men, and $>20 \mathrm{~g} /$ day in women [22].

38 (47.5\%) cases were positive for HBV (positive for any one marker). $\mathrm{HBs} \mathrm{Ag}$ was positive in 22 cases, anti$\mathrm{HBc}$ IgM in 7 cases and anti-HBc IgG in 29 cases. 4 (5\%) cases were positive for anti HCV. Three $(3.75 \%)$ cases showed coinfection of HBV \& HCV.

A study conducted by Chakravarti et al at New Delhi, showed that $80(60.6 \%)$ cases were positive for HBV infection using all the three markers. $\mathrm{HBs} \mathrm{Ag}$ was positive in 44 cases, anti-HBcIgM in13casesand anti$\mathrm{HBc}$ IgG in 80 cases. Twenty-seven (79.41\%) cases showed coinfection with HBV \& HCV [18].

The prevalence of HBV and HCV dual infection in this study was low. Higher prevalence of coinfection were reported by other studies in patients on haemodialysis (3.5\%), patients undergoing organ transplantation (8\%), and injection drug users $(42.5 \%)$ [21, 23, 24]. The difference in the magnitude of co-infection among these studies and our study could be due to difference in the study population, geographical variation, and difference in methodology. In this study, cases of HBV associated CLD were higher than HCV associated CLD. Similar pattern was reported in Ethiopia with $6.2 \%$ and $1.7 \%$ [25]. In a study by Tessema et al. the prevalence of $\mathrm{HBV}$ and $\mathrm{HCV}$ was $4.1 \%$ and $0.7 \%$, respectively [26].

In Vietnam, the prevalence of CLD due to HBV and HCV was $47 \%$ and $23 \%$, respectively [27]. Contrary to these reports, higher prevalence of $\mathrm{HCV}$ to $\mathrm{HBV}$ in Pakistan, 64.9\% HCV versus 24.7\% HBV [28] higher HCV prevalence of $73.5 \%$ was reported among patients with CLD in Egypt [29]. The higher prevalence in these studies could be due to geographical variation [30].

41 cases of CLD in the present study were cryptogenic (negative for both HCV and HBV). It has been shown that $7.3 \%$ cases of HBV were detected only on the basis of HBV DNA where all others markers for HBV were absent [31]. We might have missed few cases infected with either of these two viruses since we have not tested the presence of HCV RNA and HBV DNA. This can also be due to the presence of other hepatotropic viruses like hepatitis G virus (HGV) or transfusion transmissible virus (TTV) or SEN viruses.

\section{Conclusion}

All CLD patients should be tested for HBV and HCV to prevent the mortality and morbidity. HBV being a vaccine preventable disease, it is possible to prevent the disease by proper measures of prevention and immunization and thereby preventing the morbidity and mortality caused by these diseases. Educating the community about the spread of the disease and appropriate preventive measures helps to prevent its spread in the community. Also, it is suggested that proper screening of all chronic liver disease patients should be done for HBV and HCV and its co-infection to know serostatus. Early detection of these diseases 
will be helpful for proper treatment and preventing its progression to chronicity, there by morbidity and mortality can be reduced.

What new in this study: The patients were screened for HBs Ag along with anti-HBc IgM and anti-HBc IgG antibodies as markers of $\mathrm{HBV}$. So sensitivity and specificity increased for detection of HBV. The patients were also screened for anti-HCV antibodies. Thus HBV \& HCV coinfection should not be excluded by negative HBsAg status alone.

Funding: Nil, Conflict of interest: None initiated Permission from IRB: Yes

Contribution- Study concept, Data collection, Manuscript writing: Dr. Vilas B N. Data collection, Manuscript writing, Manuscript editing, final review and approval: Dr. Lyra P R. Study design and final approval: Dr. Venkatesha D.

\section{References}

1. Crockett SD, Keeffe EB. Natural history and treatment of hepatitis $\mathrm{B}$ virus and hepatitis $\mathrm{C}$ virus coinfection. Ann Clin Microbiol Antimicrob. 2005;4 : 13. doi:10.1186/1476-0711-4-13.

2. Benvegnu L, Fattovich G, Noventa F, Tremolada F, Chemello L, Cecchetto A, Alberti A. Concurrent hepatitis $\mathrm{B}$ and $\mathrm{C}$ virus infection and risk of hepatocellular carcinoma in cirrhosis. A prospective study. Cancer. 1994;74:2442-8.

3. Chiaramonte M, Stroffolini T, Vian A, Stazi MA, Floreani A, Lorenzoni U, et al. Rate of incidence of hepatocellular carcinoma in patients with compensated viral cirrhosis.Cancer. 1999 May 15;85 (10):2132-7

4. Weltman MD, Brotodihardjo A, Crewe EB, Farrell GC, Bilous M, Grierson JM, et al. Coinfection with hepatitis Band $\mathrm{C}$ or $\mathrm{B}, \mathrm{C}$ and delta viruses results in severe chronic liver disease and responds poorly to interferon-alphatreatment. J Viral Hepatol. 1995;2 (1): $39-45$.

5. Lee WM. Hepatitis B virus infection. N Engl J Med. 1997; 337: 1733-45. doi: 10. 1056/ NEJM 199712113 372406

6. Chaudhuri V, Tayal R, Nayak B, Acharya SK, Panda SK. Occult hepatitis B virus infection in chronic liver disease: full-length genome and analysis of mutant surface promoter. Gastroenterology. 2004; 127: 1356-71.

\section{Original Research Article}

7. Sy T, Jamal MM. Epidemiology of hepatitis $C$ virus (HCV) infection. Int J Med Sci2006; 3 (2):41-6. doi:10. 7150/ijms.3.41.

8. Lok ASF, McMahon BJ. Chronic hepatitis B. Hepatology 2007 ;45(2):507-39.doi:10.1002/hep.21513.

9. Centers for Disease Control and Prevention. Recommendations for prevention and control of hepatitis $\mathrm{C}$ virus (HCV) infection and HCV-related chronic disease. MMWRRecomm Rep1998;47(RR-19): 1-39.

10. Davis GL, Albright JE, Cook SF, Rosenberg DM. Projecting future complications of chronic hepatitis $\mathrm{C}$ in the UnitedStates. Liver Transpl. 2003 Apr;9(4):331-8. doi :10.1053/jlts.2003.50073.

11. Liu CJ, Liou JM, Chen DS, Chen PJ. Natural course and treatment of dual hepatitis $\mathrm{B}$ virus and hepatitis $\mathrm{C}$ virus infections.J Formos Med Assoc2005;104:783791. doi :10.1007/s12072-009-9147-9.

12. Chen DS, Kuo G, Sung JL, et al. Hepatitis C virus infection in an area hyperendemic for hepatitis B and chronic liver disease: theTaiwan experience. J Infect Dis 1990;162:817-822.doi: 10.1093/infdis/162.4.817.

13. Sagnelli E, Coppola N, Messina V, et al. HBV superinfection in hepatitis $\mathrm{C}$ virus chronic carriers, viral interaction, and clinicalcourse. Hepatology 2002;36: 1285-12891.doi:10.1053 /jhep.2002.36509.

14. Liaw YF, Chen YC, Sheen IS, Chien RN, Yeh CT, Chu CM. Impact of acute hepatitis $\mathrm{C}$ virus superinfection in patients with chronic hepatitis B virus infection. Gastroenterology 2004;126: 1024-1029.doi; $10.1053 /$ j.gastro.2004.01.011.

15. Saravanan S, Vijayakumar et al. Hepatitis B virus and hepatitis $\mathrm{C}$ virus dual infection among patients with chronic liver disease. J Microbiol Immunol Infect. 2009; 42 (2) :122-128.

16. Devi KS, Singh NB, Mara J, et al. Seroprevalence of hepatitis B virus and hepatitis $\mathrm{C}$ virus among hepatic disorders and injecting drug users in Manipur - a preliminary report. Indian J Med Microbiol2004; 22 (2): 136-7.

17. Xess A, Kumar M, Minz S, et al. Prevalence of hepatitis $\mathrm{B}$ and hepatitis $\mathrm{C}$ virus coinfection in chronic liver disease. Indian J Pathol Microbio 12001; 44 (3): 253-5. 
18. Chakravarti A, Verma V, Jain M, et al. Characteristics of dual infection of hepatitis $\mathrm{B}$ and $\mathrm{C}$ viruses among patientswith chronic liver disease: a study from tertiarycarehospital.TropGastroenterol2005;26(4):183-7

19. Liaw YF. Role of hepatitis $\mathrm{C}$ virus in dual and triple hepatitis virus infection. Hepatology. 1995; 22 (4):1101 -1108.doi:10.1002/hep.1840220413.

20. Kundu A, Mehta S et al.Prevalence of Hepatitis B Virus and Hepatitis-C Virus among Chronic Liver Disease Patients in Northern Haryana Region of India. www.jkscience.orgVol. 17 No. 4, Oct - December 2015.

21. G. A. Reddy, K. V. Dakshinamurthy, P. Neelaprasad, T. Gangadhar, and V. Lakshmi. Prevalence of HBV and HCV dual infection in patients on haemodialysis. Indian Journal of Medical Microbiology, vol. 23, no. 1, pp. 41-43, 2005.

22. Kooffreh-Ada1 M,Okpara H, Oku A, Okonkwo Uet al. Risk factors of chronic liver disease amongst patients receiving care in a Gastroenterology practice in Calabar. IOSR Journal of Dental and Medical Sciences.Volume 14, Issue 12Ver.V(Dec. 2015), 06-13.

23. A. Aroldi, P. Lampertico, G. Montagnino et al. Natural history of hepatitis B and C in renal allograft recipients. Transplantation, vol. 79 , no. 9, pp. 11321136, 2005.

24. J. R. Pallás, C. Fariñas-Álvarez, D. Prieto, and M. Delgado-Rodríguez. Coinfections by HIV, hepatitis B and hepatitis $\mathrm{C}$ in imprisoned injecting drug users. European Journal of Epidemiology, vol. 15, no. 8, pp. 699-704, 1999.

25. B. Gelaw and Y. Mengistu. The prevalence of HBV, $\mathrm{HCV}$ and malaria parasites among blood donors in Amhara and Tigray regional states. Ethiopian Journal of Health Development, vol. 22, pp. 3-7, 2008.

\section{Original Research Article}

26. B. Tessema, G. Yismaw, A. Kassu et al. Seroprevalence of HIV, HBV, HCV and syphilis infections among blood donors at Gondar University Teaching Hospital, Northwest Ethiopia: declining trends over a period of five years," BMC Infectious Diseases, vol. 10, article 111, 2010.doi: 10.1186/14712334-10-111.

27. S. Kakumu, K. Salo, and T. Morisrila.Prevalence of hepatitis B, hepatitis C and GB virus C / hepatitis G virus infections in liver disease patients and inhabitants in HO Chi Minh, Vietnam. Journal of Medical Virology, vol. 54, pp. 243-249, 1998. doi: 10.1155/ $2013 / 563821$.

28 N. Bukhtiari, T. Hussain, M. Iqbal, A. M. Malik, A. H. Qureshi, and A. Hussain. Pakistan-US laboratory for sero-epidemiology, Army Medical College, Rawalpindi. Journal of the Pakistan Medical Association, vol. 53, pp. 136-140, 2003.

29. I. A. Waked, S. M. Saleh, M. S. Moustafa, A. A. Raouf, D. L. Thomas, and G. T. Strickland. High prevalence of hepatitis $\mathrm{C}$ in Egyptian patients with chronic liver disease. Gut, vol. 37, no.1, pp. 105-107, 1995.

30. C. H. Chen, P. M. Yang, G. T. Huang, H. S. Lee, J. L. Sung, and J. C. Sheu. Estimation of seroprevalence of hepatitis $B$ virus and hepatitis $C$ virus in Taiwan from a large-scale survey of free hepatitis screening participants. Journal of the Formosan Medical Association, vol. 106, no. 2, pp. 148-155, 2007. doi :10. 1016/ S0929-6646 (09) 60231-x.

31. Sarin SK, Guptan RC, Banerjee K, Khandekar P. Lowprevalence of hepatitis $\mathrm{C}$ viral infection in patientswith non alcoholic chronic liver disease in India. JAPI1996; 44:243-245.

\section{How to cite this article?}

Vilas BN, Lyra PR, Venkatesha D. Coinfection of hepatitis B and hepatitis C virus among chronic liver disease patients in a tertiary care centre. Trop J Path Micro 2018;4(2):128-133. doi: 10.17511/jopm.2018.i2.01 